\title{
BUSINESS DIRECTED BY AN ARISTOCRAT: THE ESTABLISHMENT AND FIRST YEARS OF THE TEXTILE FACTORY AT UHROVEC (1845-1851)
}

\author{
EVA K O WA L S K Á
}

\begin{abstract}
KOWALSKÁ, Eva. Business Directed by an Aristocrat: the Establishment and First Years of the Textile Factory at Uhrovec (1845-1851). Historický časopis, 2019, 67, 5, pp. 809-837, Bratislava.

The (Fein) Tuchfabrik at Uhrovec was established in a region that apparently lacked material and infrastructure pre-conditions. However, the project had another comparative advantage - the strong capital of the owner, a rich aristocrat with connections that enabled him to successfully establish himself in the economic space of Upper Hungary. Count Karl Zay was a supporter of liberalism and of progressive business aims such as railways and steam ships. The factory had various company shops and a network of customers across the Kingdom of Hungary. In the revolutionary period it began to profit from supplying the army, county units and the gendarmerie or police. However, state orders were also a risk factor in the form of unrealistic conditions from the side of customers, which gradually began to threaten the profitability of the business. At the beginning of this cooperation, the factory immediately began to make losses, which began to threaten its functioning.

The study analyses the process of establishment of the factory, the financial questions of building and equipping it, the questions of personnel and the material functioning as well as the social security of the workers, a large proportion of whom were women.
\end{abstract}

Key words: Kingdom of Hungary. Uhrovec. Karl Zay. History of manufacturing. Textile industry. $19^{\text {th }}$ century.

DOI: https://doi.org/10.31577/histcaso.2019.67.5.2

“... derselbe weder von den Erträgnissen der Fabrik zu leben, noch sich diesfalls fremden Ansichten zu unterordnen genöthigt ist..."

The industrialization of the Kingdom of Hungary progressed only slowly from the beginning of the 19th century with a phase shift compared to other parts of Europe including other parts of the Austrian Monarchy. Moreover, it had a spe-

1 Pressburger Zeitung 4 April 1845, p. 203. Accessible online (viewed 5 Feb 2017): http:// pc139.ulib.sk/search/i.jsp?pid=uuid:1 ec30e40-d452-11de-8dc5-000d606f5dc6\#periodical-periodicalvolume-periodicalitem-page_uuid:9554a2f0-d5d0-11df-b1d2-000d606f5dc6 
cific feature that significantly influenced its course and form: at the beginning members of important aristocratic families were the main protagonists of industrialization. ${ }^{2}$ The owners of extensive estate complexes had varied resources, which could be used in various fields for longer or shorter periods, depending on various circumstances to achieve considerable prosperity. ${ }^{3}$ Their property relations, extensive system of privileges and share in the exercise of political power enabled them to undertake industrial production from a more favourable starting line compared to members of other classes, including those with property. Their standard revenues could easily be enriched with the profits from various types of industrial enterprise. ${ }^{4}$ The agrarian character of Hungary, maintained by the government and the extensive lands mainly in the hands of the nobility, oriented the interest of entrepreneurs mainly towards the industrial processing of agricultural products. ${ }^{5}$

2 On the business activities of the Andrássys see LÖRINČÍKOVÁ, Silvia. Podnikanie aristokracie v oblasti baníctva a hutníctva v 19. storočí na príklade grófa Juraja Andrássyho. (Aristocratic enterprise in the fields of mining and metal production in the 19th century, using the example of Count George Andrassy). In Montánna história. Ročenka o dejinách baníctva a hutníctva. Limbach: Slovenská spoločnost' pre sociálne a hospodárske dejiny, 2011, no. 3, p. 254-259. ISBN 9788097097301.

3 The Holič-Šsaštin estate complex, a Habsburg property, is a representative example. On this see ZEDINGER, Renate. Franz Stephan von Lothringen (1708-1765). Monarch, Manager, Mäzen. Wien; Köln; Weimar: Böhlau, 2008, p. 224-231. ISBN 3205781090; RAGAČ, Radoslav - FIALOVÁ, Ivana. Stopy hospodárskych aktivit Františka Štefana Lotrinského na cisárskom panstve Holič. (Traces of the economic activities of Francis Stephen of Lorraine on the imperial estate of Holič). Bratislava: Regionálna rozvojová agentúra Skalica, 2011. ISBN:9788097031732; ČERVENKOVÁ, Ivana. Panstvá cisára Františka Štefana Lotrinského v Šaštíne a Holíči ako príklad efektívne fungujúceho hospodárstva. (The estate of Francis Stephen of Lorraine at Šaštin and Holič as an example of an effectively functioning business). In KUŠNIRÁKOVÁ, Ingrid a kol. „Pre blaho nášho l’udu, všetkých našich královstiev a provincii". Reformná politika Márie Terézie a jej pokus o modernizáciu Uhorska. Bratislava: HÚ SAV; Veda, 2016, p. 197-218. ISBN 9788015347; GEPP, Christian. Grundherrschaft Holíč - eine witrschadftliche Betrachtung der Jahre 1735-1765. In KUŠNIRÁKOVÁ, ,,Pre blaho nášho l'ud,... ", p. 219-229. People from outside the nobility were also active in mining, especially in the Spiš-Gemer mining district. For more details see LACKO, Miroslav. Štátne financie habsburskej monarchie a uhorská med'v období vojny o rakúske dedičstvo. Štát kontra súkromní t’ažiari. (The state finances of the Habsburg Monarchy and Hungarian copper in the period of the War of the Austrian Succession. The state against private miners). In Historický časopis, 2015, year 63, no. 1, p. 3-26. ISSN 0018-2575.

4 ŠPEISZ, Anton. Manufaktúrne obdobie na Slovensku. (The manufacturing period in Slovakia). Bratislava: Vydavatel'stvo SAV 1961, p. 262-267.

5 VADKERTYOVÁ, Katarína. Dejiny cukrovarníckeho priemyslu a pestovania cukrovej repy na Slovensku $(1800-1918)$. (The history of the sugar refining industry and sugar beet production in Slovakia (1800 - 1918).). Bratislava: Veda, 1972. 
In the framework of the Hungarian nobility or aristocracy, extensive estates spread across various typologically very different parts of the kingdom were not exceptional. Although inheritance often brought fragmentation, rational economic activity and enterprise by owners, combined with advantageous marriage policies, could provide enough resources for a comfortable way of life. An example of the use of the potential of a family's own property and personal possibilities is the reconstruction and launching of the economic rise of the important estate of the Zay family of Bučany and (Zay-) Uhrovec. They were an old family, who had gained the rank of baron in 1560, which meant a higher level in the hierarchy of the Hungarian nobility. They gained a leading position in the political elite for a time as a result of strict adherence to a Lutheran confessional identity. ${ }^{6}$

In the course of the 18th century, members of the family continued to hold leading positions in the community of Lutherans in Hungary, so that they again reached the highest level of the aristocracy with the granting of the title of count in 1830. This rise enabled Karl Zay to achieve the position of General Inspector of the Church, as his grandfather had before him, and to play a leading part in the reform movement and revolution of 1848. However, he not only had a place on the political and ecclesiastical scenes. He made equally important contributions to the development of railways and especially of the textile industry, which was represented by the textile factory he established at Uhrovec.

The factory, called at the time the Ugroczer (Fein)Tuchfabrik) was important for the whole Kingdom of Hungary and even more for the micro-region in which it operated. ${ }^{7}$ Its origin and functioning through the whole period of its existence have already been comprehensively studied. ${ }^{8}$ However, the rich archive collection still offers material for an analytical view, so in this study, I have concentrated on the period I consider most interesting, namely from the beginning to the early 1850s. During this period, the owner, directors and employees had to deal with the process of erecting the factory buildings, equipping them, starting pro-

6 A comprehensive account of the family was most recently worked out by FUKÁRI, Valéria. Felsö-magyarországi föúri családok. A Zayak és rokonaik 16. - 19. század. (The aristocratic families from Upper Hungary. The Zays and their relatives in the 16th - 19th centuries). Pozsony: Kalligram, 2008. ISBN 9788071499718.

7 An otherwise well researched monograph on the village devotes only limited attention to the factory, with the authors noting especially the technical aspects of production: ŠIŠMIŠ, Milan - BEŠTOVÁ, Elena - KVASNICOVÁ, Ol'ga. Uhrovec. Uhrovec: Obec Uhrovec, 2007, p. 44. ISBN 9788096966813.

8 KRAJČOVIČOVÁ, Klára. Továreň na súkna v Uhrovci (1845 - 1873). (The textile factory at Uhrovec (1845-1873).). In Zbornik SNM, 1972, year 66, História 12, p. 135-164; an older study: SZTUDINKA, Ferenc. Gróf Zay Károly zay-ugróczi volt posztógyárának története (1845-1872). (History of the textile factory of Count Karl Zay of Zay-Uhrovec (1845-1872).) (=Magyar ipartörténet, III), Budapest 1909. 
duction, continuing their work during the complex period of the revolutionary years and seeking regular customers.

Over the course of a few years, it is possible to trace the origin of an enterprise "on a green field", its steps to achieving optimal production and profit, analyse the importance of state orders and the share of domestic and non-resident in its successes and failures. The enterprise can serve as an example of business aims pursued in a not entirely typical industrial environment and away from the main lines of communication. It is especially interesting to trace how the problems standing in its way could be overcome.

\section{The estates of the Zay family of Uhrovec and Bučany}

The first visible trace of the Uhrovec textile factory in the history of business can be seen in an advertisement published in the Pressburger Zeitung on 4 April 1845 announcing the imminent opening of the textile factory. The business aim of the owner to use his own capital to benefit not only his own economic position, but also the development of the whole country, was clearly stated. ${ }^{9}$ Understandably, construction and organizational work was already under way to achieve these aims in the form of a new, modern building equipped with foreign machinery and employing people from the near and more distant surroundings.

The prehistory of the enterprise that symbolized modern trends can be traced in the development of the Zay estates going back to the last third of the 18th century. The relatively stable property of Baron Peter Zay, composed of a basic inherited part - the Lordship of Uhrovec - and further parts added to the family "portfolio" thanks to his marriages, got into serious difficulties. Peter Zay's first and third marriages - to Eleonóra and Lujza Amália, both born Kalisch (Calisius, Kališ, from the family seat of Kalisz in Poland) brought as their dowries claims to properties at Malé Bierovce and Bytčica, but also at Sobotište and Skalica. His second wife, Maria Francisca was a member of the Auersperg family of Counts of the Holy Roman Empire, but her father did not have very large properties. Peter Zay could have theoretically claimed part of the Auersperg property, namely a house in Sopron, but his strained to hostile relations with the Auersperg family and the death of his wife complicated or it is better to say thwarted such ideas. Peter's son Imrich Richard became the actual heir to the Auersperg properties. ${ }^{10}$

For Peter Zay, who aspired to and from 1758 actually achieved an important position in the Evangelical Church of the Augsburg Confession, the property

9 Ref. 1.

10 The inheritance fell to him only after 1800 . Peter Zay had six sons and one daughter, but only Sigismund and Imrich reached maturity, and the family line continued through Imrich. See also FUKÁRI, ref. 6. 
concentrated around the not very important Uhrovec and its lordship was rather unsatisfactory. The family's original seat was a medieval castle or manor house, already decayed by the 18 th century. ${ }^{11}$ One wing of it belonged to the family of the Catholic Ladislav Kolonich, originally named Zay. His marriage to a member of an important family, conversion to Catholicism and adoption by the Bishop of Vienna was a classic example of the effort to preserve the family property of the Kollonich family that was dying out. The town mansion at Skalica, which came to the Zay family portfolio through a share of the Calisius (Kalisz) inheritance, did not bring much profit. ${ }^{12}$ It was let to tenants under conditions that were so unclear that at the time of a property dispute at the beginning of the 19th century the real ownership of the house was ascertained only with difficulty. ${ }^{13}$

These complicated property relations certainly did not provide sufficient basis for the politically and ecclesiastically important position of general inspector and the dignity of chamber councillor, which Peter Zay gained. According to the authentic statement of Peter's son Imrich, it was his step-mother, Peter's last wife, who initiated the purchase of the extensive lordship and manor house at Bučany. Although the property was on fertile soil and close to commercial and social centres, it meant a great burden. It was bought with credit and the operation of a large residence was also financially demanding. In addition, the property share of his brother, who moved from Silesia to Vienna, also increased. ${ }^{14}$ Fires in various estate villages also represented serious financial losses, amounting to 10,000 gulden only in $1786 .{ }^{15}$ To get out of debt required intensive economic activity, but for objective reasons Peter Zay could not undertake it from the position of General Inspector of the Lutheran Church. At the time of the preparation of the Toleration Patent and after it was issued, he was confronted with a multitude of tasks required for implementation of the patent. ${ }^{16} \mathrm{He}$ moved

11 On the development of property rights in relation to the castle see JANKOVIČ, Vendelín. $\mathrm{Z}$ dejín Uhrovca a tamojšieho kaštiel'a. (From the history of Uhrovec and its manor house). In Monumentorum tutela. Ochrana pamiatok XI. Bratislava 1984, p. 15-31.

12 The Calisius/Kalisz family was repeatedly connected with the Zays from the 18th century. See FUKÁRI, ref. 6.

13 The administration of the house, as far as it was in the direct possession of the Kalisz family, was done by Johann Hajny - Hajnóczi, grandfather of the famous Joseph Hajnóczi. For more details see KOWALSKÁ, Eva - KANTEK, Karol. Uhorská rapsódia alebo Tragický osud osvietenca Jozefa Hajnóczyho. (Hungarian rhapsody or the tragic fate of the Enlightenment intellectual Joseph Hajnóczy). Bratislava: Veda, 2008, p. 34-36. ISBN 9788022410342.

14 Letter from Imrich Zay to his grand-mother Auersperg from 25 May 1785. Slovak national archive (SNA) Zay, Bučiansky archív, Imrich Zay - Correspondence, carton 100, part 3, fol. 184-185.

15 SNA - Zay, Bučiansky archív, Imrich Zay - Correspondence, carton 100, part 2, fol. 118-121.

16 For more details see KOWALSKÁ, Eva. Evanjelické a. v. spoločenstvo v 18. storoči. Hlavné problémy jeho existencie a fungovania v spoločnosti. (Lutheran community in the 18th 
between Vienna, Pressburg, Buda and Pest, coming to Bučany only irregularly. The results came very quickly. By the end of the 1780s, his son Imrich was afraid that he and his younger brother Sigismund would inherit only debts from Bučany, and that his step-mother was a bad or rather light-weight business manager. ${ }^{17}$ However, Sigismund was destined to inherit the Kalisz properties from his mother, and could theoretically gain a stronger position than his brother. Imrich was not attracted by the prospect of pursuing a demanding but inadequately remunerated official post, but had long dreamed of a military career in spite of parental opposition. According to his own words, it promised a dignified life even without the support of great property, and more honourable relations between people. ${ }^{18}$ His father's relatively early death in 1788 showed that he was right: The continued management of the estates by Peter's widow put the lordships of Bučany and Uhrovec further into debt. Imrich's critical attitude towards his stepmother led to their complete estrangement, and to Imrich sometimes considering definitively leaving Hungary.

Paradoxically, his traditional respect for the wishes of his parents, even in spite of their opposition to him joining the army, entirely changed the destiny of Imrich Zay and the family property. Imrich seriously considered marrying an unnamed woman in the area he was stationed: at Liege in the Austrian Netherlands. His step-mother was well aware that this might complicate the future solution of property matters. She promptly recommended a more suitable partner: her niece, Maria Elizabeth Helena (Mimi) daughter of Johann Traugott Calisius (Kalisz). This step had a happy outcome not only in the quick growth of mutual affection, and the conclusion of marriage even at the cost of leaving the army, but also in the beginning of consolidation of the Zay family property. His bride brought the promise of a considerable dowry amounting to 72,000 gulden, although it was paid only after the death of her mother in 1799. They invested most of it $(40,000)$ in paying the debts that burdened the properties at Bučany. ${ }^{19}$ However, family events also helped to defend and enlarge the properties: The early death

century. The main problems of existence and functioning in society). Bratislava: Veda 2000, p. 132-134. ISBN 8022407046.

17 Statement by Imrich Zay in a letter to his aunt from 1 March 1789. SNA, Zay, Bučiansky archív, Imrich Zay - Correspondence, carton 101, part 2, fol. 8-9.

18 The military career of I. Zay is analysed in the study KOWALSKÁ, Eva. Dôstojník v armáde a spoločnosti na prelome 18. a 19. storočia: Imrich II. Zay a jeho kariéra $(1765-1831)$. (An officer in the army and society around 1800: Imrich II Zay and his career (1765-1831). In Vojenská história, 2015, year 19, no. 2, p. 147-160. ISSN 1335-3314.

19 After the division of the property at the time of his marriage in 1796, the Bučany property was burdened by a debt of 118,123 gulden. SNA, Zay, Bučiansky archív, Karol Zay, No. 1-156, carton 193, fasc. 1-155, fol. 258-259. 
of Imrich's brother Sigismund in 1806 meant a settlement with his step-mother. ${ }^{20}$ Although, soon after his marriage, Imrich had to spend almost 10,000 gulden on the expenses of an insurrection and repairing considerable damage from more fires ${ }^{21}$ these family events freed his hands to start business activities. From 1810, he improved the economic position on the Bučany estate with better infrastructure, such as regulated water-courses and a mill. Appropriate facilities were let to tenants, as in the case of the Bučany mill from 1821. The unclear property situation of the town house in Skalica was solved. The tenancy of Count Joseph Gvadányi was found to be legally unsupported. ${ }^{22}$ After the settlement, it was let out again for a long period from $1815 .{ }^{23}$ The Zay properties increased most after the death of General Maximilian Kollonich, the last of his family, in 1827, which led to Karl Zay gaining the Kollonich share of the Uhrovec manor house and lordship in 1833. The reverse side of this acquisition was the need to take over enormous debts, which had to be paid from the profits from other properties.

Improvement also started on the Uhrovec estate, which had long been left in a secondary position compared to the potentially and eventually actually more lucrative Bučany. The latter began to yield substantially more and it provided more comfort for the life of an aristocratic family. It lay on the edge of the territory of Trnava and near railways, which became an important factor in economic development from the end of the 1840s. By railway it was not far from Pressburg, Vienna and Sopron. In the last of these, the family owned a house inherited from the Auersperg grandparents. Imrich lived there in the first period after his marriage, and his son Karl spent his first school years there. Uhrovec was attractive especially in summer. After 1814 prominent guests from Vienna including the writers Caroline Pichler and Franz Grillparzer as well as high-ranking officers. The notable poetess Theresia Artner also found a home and support here for several years in this period. ${ }^{24}$ Although the village and its surroundings were

20 In spite of this, their relationship did not improve and the Baroness made the Pressburg Lutheran community the general heir to her share of the property.

21 Soon after the wedding of the young Zays, buildings near the manor house of Uhrovec were burnt in a fire that started in a nearby distillery. In 1800 storms caused fires at various localities in the Bučany estate (Podolie, Vrbové, Častkovce). SNA, Zay, Bučiansky archív - Karol Zay, carton193, fasc. 1-155, fol. 278-279.

22 On this see, Zay, Bučiansky archív - Various, Imrich and Karl Zay, carton 116, fasc.4, fol. 14-15.

23 Tenancy agreement in the SNA, Fund Zay, Bučiansky archív - Various, Imrich and Karl Zay, carton 218, fasc. 9, fol. 102.

24 JÓNÁSOVÁ, Anna. Literárny salón - spôsob literárnej komunikácie v 17. - 19. storočí. Pokus o otvorenie literárnohistorickej témy. 2. čast'. (The literary salon - a method of literary communication in the 17th -19 th centuries. An attempt to open a literary historical theme. Part 2). In Knižnica, 2011, year 12, no. 5, p. 45-48. 
picturesque, the whole extensive lordship did not bring much income. Up to 1808 , the annual profit was less than 5,000 gulden. The Uhrovec valley was not very favourable for plant production, but it had extensive forests and good conditions for keeping sheep. Precisely the keeping of sheep for wool was the usual strategy for increasing income during the boom in the period of insurrections, wars with Napoleon and variable climate. ${ }^{25}$ The finances of Uhrovec began to stabilize, and in the period 1809-1813, the profit grew to about 10-11 thousand gulden. So that the wool could be used in the place of production, the lordship acquired a new fulling machine in 1813 and agreed that master weavers could use it at Uhrovec for three years in return for a low rent of 100 gulden per year paid in four instalments. ${ }^{26}$

It is noteworthy how Imrich Zay was able to defend and improve properties burdened by various debts even without the corresponding education. His university study at Leipzig was not very intensive, and considerable time was spent perfecting the "noble arts" of horse riding and fencing. The majority of his letters sent home to his parents concerned shortage of money, which did not allow him a student life "appropriate to his class", which meant more society and theatres than lectures and libraries... The society in which he moved, especially his friendship with Christian son of the imperial General Dagobert Sigmund Wurmser, and the unclear prospects for his future application and security, led to him joining the army after only two years in Leipzig. This realized his childhood "inclination towards the military life"27 and long-term resistance to the "economic" and civilian life. With his unit he experienced military action in a siege of Belgrade, as well as stationing in the Austrian Netherlands, where he had the possibility to observe the organization and functioning of a progressive, developing society.

Imrich Zay's letters home also include observations on the maturity of Antwerp and Brabant. His illegal trip to London can also be regarded as a sort of study trip to gain knowledge. Since he was confronted with this foreign environment already as an adult, he understood his brief stay as an opportunity to gain experiences and intensive observations. However, he did not rely only on this not very systematically acquired knowledge: He also added to his library ex-

25 On the natural catastrophe of 1815 HOLEC, Roman. Ako človek prestával byt' vládcom prírody. (How mankind ceased being the master of nature). In Forum Historiae, 2017, year 11, no. 1. ISSN 1337-6861. A review of the founding initiatives of the period can be found in ŠPIESZ, Anton. Manufaktúrne obdobie na Slovensku 1725-1825. (The manufacturing period in Slovakia). Bratislava: Vydavatel'stvo SAV, 1961, p. 177-200.

26 SNA, Zay, Prefect - Inspector of lordships, Economic accounts,carton 406, no. 38, fol. 15.

27 He mentions it as something significant in his correspondence, identifying it as something going back to his childhood. SNA, Zay, Bučiansky archív, Imrich Zay - Correspondence, carton 100 , part 3 . 
pert works on economics and agriculture, including Fándly's work. He ordered similarly oriented journals and exchanged letters with recognized authorities on economic theory such as the Austrian economist Franz Graf von Enzenberg and Johann Friedrich Mayer. Imrich could also appreciate the economic potential of new inventions and innovations. He endeavoured to apply new technology to the production of sugar, ${ }^{28}$ agricultural machines, the cultivation of fast growing timber, specifically locust tree/false acacia trees, and he expected rapid development in the field of transport: He was one of the first to invest in the Donau-Dampffschiffahrts-Gesellschaft, buying two shares at a cost of 200 gulden. ${ }^{29}$ Imrich's effort did not remain without success. Already during his life, he was not only able to defend the family property, but also to free it from debts and lay the foundations for its later expansion into other spheres of business.

Imrich's son Karl (12 February 1797 - 8 October 1871) followed in his father's footsteps. Some degree of similarity to his father can already be seen in the fact that he did not complete a systemic university education. Study at the Royal Academy in Pressburg was enough for the type of career for which he was pre-destined..$^{30} \mathrm{He}$ also did not hold classic "employment", but a function connected with the current tasks of a chamber councillor (1827). For example, during the cholera epidemic of 1830-1831 he held the post of commissioner responsible for sanitary measures.

Later he engaged as an independent journalist or regular correspondent for various Hungarian and German papers, and politician, for example as a member of the parliamentary commission on questions connected with mining in 1830 . His most important post was general inspector of the Evangelical Church of the Augsburg Confession from 1840. For an aristocrat of his rank it was obligatory to regularly participate in sessions of the casino, the typical social club of that period (he chaired it in Trnava from 13 January 1839, and was on the committee

28 In 1811 he already undertook experiments with the production of sugar from sugar beet using the methods of Hermbstädt and Achard. He probably relied on their works HERMBSTÄDT, Sigismund Friedrich. Anleitung zur praktisch-ökonomischen Fabrikation des Zuckers, und eines brauchbaren Syrups aus den Runckelrüben. Berlin 1811 and ACHARD, Franz Carl. Die Zucker- und Syrups-Fabrication aus Runckelrüben. Breslau 1811. A comparison of the two methods was published by Professor K. A. Neumann in the Journal für Chemie und Physik, Vol. 4, 1812, p. 259-303 and 348-361.

29 On 15 July 18211000 shares were issued with a nominal value of one hundred gulden each. 500 shares were offered for sale and 232 of them were sold by the end of November 1822 . Imrich bought shares no. 43 and 44. The first investor was Johann von Szallopek. SNA, Zay - Bučiansky archív, Imrich Zay - Correspondence, carton 111, Fasc. I, fol. 146-153.

30 NOVÁK, Veronika M. A pozsonyi jogakadémia hallgatósága 1777-1849. (The students of the Law Academy of Pozsony in 1777-1849). Budapest: MTA Egyetemtörténeti Albizottságe: ELTE Levéltára, 2007, p. 244. ISBN 9789634638988. 
in Pest), attend meetings of parliament and incline to ideas of national economic protectionism and the liberal movement.

His interests did not remain only on the theoretical level: He considered an offer of a place on the board or top management of a joint stock company with the aim of reviving the textile factory at Šaštín. ${ }^{31}$ Already at home, he had his father as an example of rational and successful enterprise by an aristocrat, so after Imrich's unexpected death on 18 August 1831,32 Karl undertook increased business activity. He could draw inspiration not only from theoretical literature. In this period the popular and appreciated Friedrich List was not only read in Hungary but also heard: He gave lectures in Pressburg and directly or indirectly stimulated the establishment of joint stock companies. ${ }^{33}$

\section{The question of the financial and material securing of business projects}

Establishing a factory and in a location like Uhrovec was inevitably associated with a high level of risk. This applied equally to those with enough of their own capital and to those who obtained it by public participation. The bank credit system in Hungary was only just emerging, so the rather uncertain route of issuing and selling shares was sometimes used, as at Köszeg, Győr and Levoča, where textile manufacturing was planned at the same time as at Uhrovec. ${ }^{34}$ Karl Zay did not need to take this route: Even before publishing a notice on the opening of the factory, he had 241,000 gulden, which he had already deposited in its account in 13 instalments in the course of 1844 . He also deposited resources in the factory account later, mostly according to need and his own possibilities: In 1846 he deposited 56,790 gulden, while in 1847 he made a temporary deposit of 21,000 gulden, from which he later withdrew $6 \%$ interest. ${ }^{35}$ However, he was

31 Letter from Rudolf Puthony from 20 May 1845 with the relevant offer. SNA, Zay - Bučiansky archív, Karol Zay-Correspondence, carton 138, fasc. 14, fol. 216-217.

32 Imrich Zay died of cholera soon after gaining an important recognition of his achievements in the form of elevation to the rank of Count on 12 November 1830 . He did not pay attention to the first signs of illness and underestimated the need for treatment.

33 HOLEC, Roman. Friedrich List, Ochranný spolok a Slovensko. (Friedrich List, the Protection Society and Slovakia.). In Studia Historica Nitriensis VII. Nitra 1998, p. 97-126. ISBN 9788080502270. On the establishment of joint stock companies see the next note.

34 According to a notification in the Pressburger Zeitung from 13 Dec 1844, a factory in Levoča was discussed on 3 Dec 1844. According to a report in the same newspaper on 5 May 1845 the organizing committee planned to issue 1,500 shares costing 100 gulden each. Actual work on the project would begin only after 800 shares were sold. The same newspaper published notices from the burghers of Köszeg on 28 Oct 1844, also 9 Dec 1844 and 13 Jan 1845; a notice on the establishment of a joint stock company for a factory at Györ 23 April 1845.

35 SNA, Zay - Súkenka, Účtovné knihy, Cassa-Buch 1846-1850, carton 578: Prima-nota Buch der Zay-Ugroczer Tuch Fabrik für das Jahr 1846. 
not the only person to invest some of his spare money in the enterprise. The factory fund served as a sort of savings bank. ${ }^{36}$ In the initial period, savings were also provided by B. Gudenam, the Lutheran Church community in Pressburg, a certain Mr. Gyöngyély, Magdalena and Mathias Stanzel and von Forster. They were paid 2,494 gulden and 10 kreuzer in interest for 1845 . Their example was also followed by Professor Wilhelm Schimko, who deposited 5,000 gulden for a shorter period. Then he withdrew the whole sum with interest of almost 80 gulden Deposits in the fund later increased, especially from K. Zay, who provided considerable sums according to his possibilities. In the course of 1846 he deposited 56,790 gulden, and in March 1847 a further 21,000 gulden. However, he also saw these deposits as a form of loan and he sometimes took the usual $6 \%$ interest. However, in problematic periods he refused the payment of interest.

The available capital was naturally not left inactive until the launching of production. It was used to pay necessary expenses, including insurance premiums on the factory as it was built. By the end of 1845, these payments reached an amount of 213,463 gulden. Part of the capital was deposited to earn interest with the Industrie und Handels Verein of Pest (2,000 gulden ) or savings banks (about 4,500 gulden).

Apart from initial capital, Zay had a suitable site and other necessary infrastructure. The necessary building stone, clay and sand could be quarried in the region. There was enough water to drive machinery, and plenty of locally produced wool. On the other hand, however, a significant negative factor was the isolation of the region, situated away from important communications even from the post roads. It was fifteen post stations from Pressburg, with the nearest in Trenčín and that was a four hour journey away even at the end of the 1840s. A nearer post station at Bánovce was opened only on 16 April 1850. It accelerated the movement at least of letters and money. The building of railways in Hungary began to be considered only in the 1840 s, and railway tracks remained distant from Uhrovec for a long time. Transport of products to their markets and bringing of raw materials and equipment had to be done by means of carts. These long distance carts were organized mainly by local and Bánovce Jewish "transporters" or transport firms (Israel Kacser, Ksinan). Various carters were regularly on the road, securing cart-loads to Pest and Pressburg, where goods transported by boat or later railway were loaded or delivered. A second transport line went to Uherské Hradište, terminus of one of the branches of the Nordbahn. Especially machines, dyes and chemical raw materials came by this route from various German and Austrian towns

36 In the cases of the towns of Györ, Köszeg and Levoča, independent savings bank branches were established. Information about them was published in the Pressburger Zeitung together with notifications on business plans. See note 34 . 
The dependence of the factory on road transport was already shown to be a substantial disadvantage at the time. The cost of delivering goods was high and could not be further reduced for this means of transport. The cost of delivering goods only to Pest in 1848 and 1849 amounted to 12,439 gulden, and a combination of boat and railway transport could already be used on this route. Therefore the factory gave priority to regular customers, who ordered goods according to their requirements and mostly collected them from the nearest factory shop. Saint John's markets in Pest, where contracts were concluded, were especially important for them. However, the situation on the roads in politically disturbed times also affected production and distribution. It was not only a matter of shortage of workers: Especially from the summer of 1848, uncertainty on the roads and reports of "rebels" discouraged long journeys.

However, undoubtedly the main pre-condition for the success of a business project was securing of the necessary machines. Discussion of their acquisition was under way from February 1845. Payments for machines only up to the end of that year reached 55,574 gulden. ${ }^{37}$ Zay ordered them from the regions with most developed textile production. They came from the factory owners Ernest Pflieger of Bielitz (now Bielsko-Biala in Poland) in Silesia (iron fulling machines, cylindrical shearing, finishing and brushing machines), Richard Hartmann of Chemnitz in Saxony (mechanical fulling machines, cutting machine with long knives, spinning machines), a dealer in various machines and equipment A. Heydrich from Brno, who supplied spinning and cutting machines and tables, presses and parts for fulling machines. ${ }^{38}$ Daniel Specker from the Maschinenfabrik Am Tabor in Vienna ${ }^{39}$ supplied and installed all the machines driven by steam or wa-

37 The financial report Geldrechnungen des Zay Ugroczer Tuchfabrik's Fondes von beginnungs Jahre 1845 stated for the period up to 31 Dec 1845 among other things, payment of 779 gul. for 22 weaving machines (Webzeuge), for equipping the dyeing section to copper smith Karl Straka of Skalica 4678 gul. $05 \mathrm{kr}$;; to Heydrich of Brno for components for scraping machines (Kratzmaschinen) 2965 gul. $35 \mathrm{kr}$; for a dyeing press 278 gul. $51 \mathrm{kr}$. and 78 pres plates 255 gul. $36 \mathrm{kr}$; for an iron press for cloth to the factory at Blansko 551 gul.; payment of 61 gul. $45 \mathrm{kr}$. for 12 brushes for finishing; for various ropes to Anton Kukla of Brno 272 zl. 53 gr.; for four machines for clothes finishing each $1200 \mathrm{zl}$. and other components to Ernest Pflieger of Bielsko together $6975 \mathrm{zl}$., to Hartmann of Chemnitz for finishing and spinning machines 5918 zl. 45 gr.; to Specker of Vienna (am Tábor) for water powered machines $12500 \mathrm{zl}$. SNA, Zay - Súkenka, Účty z prvého roku existencie súkenky (knihy, doklady) 1845, carton 582.

38 However, the factory sometimes also bought simpler equipment. For example, two weaving looms from Jozef Sčipek of Trnava for 20 gul.

39 For a brief description of his factory for various types of machine see Bericht über die dritte allgemeine österreichische Gewerbe-Ausstellung in Wien. Wien: Hof- und Staatsdruck, 1845, vol. 3, p. 866-867. Accessible on-line (accessed 23 Feb 2017): https://books.google.sk/books?id=I5FlAAAAcAAJ\&dq=Daniel+Specker + Am + Tabor + Wien\&hl=sk\&source=gbs_navlinks_s 
ter power. There were discussions with him already in the course of March 1845 because provision of powered machines required the construction of channels from a substantial but otherwise unregulated stream and of a supply reservoir, so that the factory would always have enough water. Provision of 16 horse-power was planned, but there was enough in reserve for future expansion and there were other streams in the district. ${ }^{40}$ It was a relatively demanding solution realized by the engineer Payne from Vienna. ${ }^{41}$ The assumption of rapid expansion soon proved to be justified. The energy arrangements had to be improved after only a year of operations. Making commercial contracts with experts was a matter for the director of the factory Rudolf Wilhelm Wrchovszký, who came from a Skalica textile producing family that established itself as a relatively important business family in the 19th century. This family business supplied some smaller machines to Uhrovec. ${ }^{42}$ However, other threads also connected the factory with Skalica - a great quantity of wool had to be spun by external partners, in this case the businesses of Paul Mittag and Ladislav Mazura. Wool from the area was also sometimes bought by another man from Skalica, Jacob Ehrenstein, the new tenant of the Zay (Gvadányi) mansion.

Machines were the main but certainly not the only pre-conditions for successful production. To get started, the factory had to secure at least some knowledge to cover the inevitably complex initial period of production. Advertising was already a regular feature of the press, and, as an experienced correspondent for various newspapers, Zay did not neglect this aspect. Apart from the domestic press represented by the Pressburger Zeitung, the opening of the factory in August 1845 was reported in various foreign newspapers. ${ }^{43}$ The factory's existence began with ceremonial "laying of the foundation stone" on 8 July 1845. Although

40 SNA, Zay - Súkenka, Corespondence, carton 592, p. 1, 2-3 (letters to D. Specker from 15 and 28 March 1845). The surface of the reservoir needed a height of more than one fathom $(\mathrm{cca} 150 \mathrm{~cm})$, to provide the necessary power.

41 This was apparently the engineer Henry Payne, originally from Stockport in England, who lived in Saxony before 1845. Payne was concerned with the development of simple spinning machines and he had a representative in Vienna. On 25 March 1844 he gained a patent for such a machine. See Sammlung der Gesetze für das Erzherzogthum Oesterreich unter der Ens, Vol. 26/1844. Wien 1846, p. 83. Accessible on-line (accessed 21 Feb 2017): https:// play.google.com/books/reader?id=ephXAAAAcAAJ\&printsec=frontcover\&output=reader\&hl=en\&pg $=$ GBS.PP6

42 For example, in 1846, $5 \mathrm{ks}$ Webstühle zu Hosenstoffe, $5 \mathrm{ks}$ Webgeschirre, 1 Jaquart Maschine were provided from Ernest Wrchovszký' workshop. SNA, Zay - Súkenka, Účtovné knihy, Cassa-Buch 1846-1850, carton 578: Prima-nota Buch der Zay-Ugroczer Tuch Fabrik für das Jahr 1846.

43 They included Vereinigte Frauendorfen Blätter, no. 4, 24 Jan 1846. Accessible online (accessed 7 Oct 2017): https://books.google.sk/books?id=1BlAAAAAcAAJ\&printsec=frontcover \&hl $=$ sk\&source $=$ gbs_ge_summary_r\&cad $=0 \# \mathrm{v}=$ onepage $\& \mathrm{q} \& \mathrm{f}=\mathrm{fal}$ 
the sources speak this language, it should have been the beginning of production, because building work already started in the course of April 1845. However, it is clear that production was not launched even on the advertised August date, and only on 8 November could the director report the completion of the building. Installation of the already delivered machines began and production gradually started. There were enough orders already from the publication of the opening of the factory. The left wing of the factory complex was also completed in May 1846. The completed factory comprised several buildings with upper floors containing production, storage space with fabric shop and probably also living accommodation for workers from localities outside Uhrovec. When planning the complex, Zay probably used the services of the builder Feigler, ${ }^{44}$ although it is not certain which of the simultaneously working architects did the work. ${ }^{45}$

Although the building was delayed, it corresponded to the up to date standards for buildings of the time. The roof was zinc-plated and there was central heating. This is shown by the delivery of two large cast-iron stoves with external heating, costing 1,800 gulden each, together with water pipes and Heiz-oder Feuerungsröster - probably meaning some sort of radiator. Work on the buildings also included attention to their outward appearance. A cast-iron fence was placed between the street and the dyeing facility, and from March 1846 the complex was protected by a hedge of 3071 hawthorn bushes.

The ceremonial laying of the foundation stone was certainly an exceptional event for Uhrovec, going beyond the level of the usual festivities. ${ }^{46}$ Zay was already planning the celebration in April 1845, when he agreed an opening speech with the Sheriff of the County of Trenčín Marczibányi. The programme, organized by Count Karl Zay's fiscal Frantz (Ferenc) Makláry-Pappsász, officer of the County of Trenčín and member of the Hungarian Economic Society (Magyar Gazdasági Egyesület), began in the morning with the arrival of guests from Bánovce - the county officers Alexander Látkóczy, Georg Ottlik and others - in a procession of coaches of members of the family, Karl Zay and the Sheriff of the County of Trenčín. The welcoming ceremony in front of the mansion opened

44 In February 1846 Mauermeister Feigler was paid 11 gul. $60 \mathrm{kr}$. for doing a revision (Schätzung).

45 The work of the Feiglers is analysed in more detail by POHANIČOVÁ, Jana - BUDAY, Peter. Storočie Feiglerovcov. Pribeh bratislavských architektov, stavitel'ov a stavebných podnikatelov. (A century of the Feiglers. The story of the Bratislava architects, builders and construction entrepreneurs). Bratislava: Trio publishing, 2016. ISBN 9788097154042.

46 On the phenomenon of celebrations see KUŠNIRÁKOVÁ, Ingrid et al. , Vyjdeme v noci vo faklovom sprievode a rozsvietime svet". Integračný a mobilizačný význam slávností v živote spoločnosti." ("We go out at night in a torch-lit procession and light up the world". The integrating and mobilizing significance of celebrations in the life of society). Bratislava: HÚ SAV, 2012. ISBN 9788089396207. 
with a musical production by three trumpeters from Bánovce on horseback, 25 bagpipers, speeches by the local Catholic and Lutheran clergy in Hungarian, and by a master of the assembled weavers' guild in Slovak (szlav nyelvben). They were followed by a 19 member choir made up of employees and local inhabitants. The guests then went into the mansion, where the stairs were decorated with orange and lemon trees and girls with flowers. They then received gold and silver commemorative medals depicting the foundation stone with a sheet of parchment bearing the name of the guest (probably addressed to each recipient). After a rest, they went in procession with musicians to the factory, where some weaving looms were already installed, but the equipment was still incomplete. More speeches were given: by the Luthera pastor of Podlužany in Hungarian, by the pastor of Uhrovec in Slovak and finally by the Catholic priest of Uhrovec in Latin. The act of laying the foundation stone was done by a master mason dressed in red. He placed with the stone a bag covering a glass vessel containing a commemorative parchment and medals. A speech from the sheriff and thanks from Zay followed. After a break of an hour, a festive lunch was served in the hall of the stables. It was accompanied by music from spa musicians from the spa of Trenčianské Teplice and toasts to the Count, his wife, the Palatine, royal family, house, sheriff, County of Trenčín and its military unit, various Hungarian noblemen and all the guests. After lunch, they sat and perhaps also played at card tables. The whole event ended with a great dinner and drinking of punch, again accompanied by music.

The ostentatious celebration was not cheap: Its expenses reached more than 1,365 gulden. The largest items were the costs of accommodation in Bánovce and Uhrovec of the invited people, including servants, coachmen and up to 170 day employees, pay for the trumpeters and musicians, as well as the cost of hospitality and wine amounting to 178 gulden. The organizers ordered 50 bottles of champagne, 64 bottles of Neustadler a popular type of red wine from the vineyards of Count Joseph Erdödy ${ }^{47}$ and a barrel of ordinary wine. They also paid for the consumption of guests during their stays at Trenčianske Teplice. The celebrations provided glamour and numerous banners painted by the artist Deutsch, decorative equipment of the assisting craftsmen, who also received new shirts, a large painted and gilded sign at the entrance to the factory, polished sabres from the castle armoury, firing of mortars, and after six evenings (from 30 June), a bonfite on Garazne hilltop. However, the accounts also include curious items: It was necessary to pay compensation to a local farmer for damage to his field while transporting wood and stone to Garazne, and for an exploded mortar, which had been borrowed from Count Nyáry.

47 This product was also advertised in the Pressburger Zeitung, 9 June 1837, p. 459. 


\section{Personnel and operational questions}

An important advantage speaking in favour of Uhrovec as the location for a factory seems to have been the local population, whose cultural level had long been cultivated by the lordship. A school with a relatively good level, from which pupils regularly went on to undertake gymnasium study, operated in this small town. Seven boys directly from Uhrovec studied in Pressburg alone in the early decades of the 19th century, and probably with support from the lordship. During the activity of Samuel Štur at Uhrovec, Imrich and Mimi Zay also secured the provision of special classes, where especially German was taught. The class had its own teacher, apparently an official of the lordship and the founding couple visited when the pupils - both boys and girls - did tests. Imrich, a master bookbinder, had a workshop in the mansion, where he cooperated with Samuel Štúr. He presented religious books, which he bound himself or in cooperation with Štúr, to various inhabitants of Uhrovec, either during his life or as bequests. This assumed that reading of books happened in the homes of ordinary peasant farmers. Domestic weaving was relatively widespread among them, weavers had their own guild in Uhrovec, and some of the workers in the factory were recruited from among them.

The size of the factory, the quantity of its output and the varied work activities, which included the servicing and maintenance of complicated machines, meant that the employees of the factory could not be found only from the limited labour market of Uhrovec and its lordship. The management of the factory had to secure conditions for the work and accommodation of workers, both male and female, also from more distant localities. ${ }^{48}$ For example, in November - December 1847, the 90 workers included 16 weavers from Uhrovec, but also 13 from localities abroad, namely Moravia, Bohemia, Prussia, Bavaria and Poland, as well as from the nearer or more distant surroundings. Therefore, the building and equipping of accommodation was one of the main tasks. They provided flats for qualified specialists, who were even housed in the mansion while the factory was being equipped. They also received allowances for lighting, heating and relocation costs. If a flat was not available, they received financial compensation. However, the generous payment conditions still did not attract enough expert personnel. As a result, orders of new machines considered the complexity or simplicity of their subsequent maintenance. Those that would not require visits from personnel of the supplying factory if they broke down were preferred. ${ }^{49}$

48105 gul. $20 \mathrm{kr}$ was paid for beds and mattresses in the factory accommodation. The order was fulfilled by the master carpenter Donay from Topol'čany. According to Auszug der Fabriks Einrichtung Ausgaben für Jahr 1845. SNA, Zay - Súkenka, Účtovné knihy, carton 591, no. 2.

4917 Sept 1850, letter addressed to the supplying factory in Chemnitz. SNA, Zay - Súkenka, 
Complex machines were not the only source of problems. The technology required an experienced dyer, on whose skill the quality of the colouring of the textiles depended. Filling of this post was not simple, and the management of the factory had to increase the benefits offered to qualified candidates. The first, Ernest Kupfer from Lindow near Neu Ruppin in the Potsdam district of Prussia, was promised 400 gulden of Konvention Münz in April 1845, but two months later, another candidate, Hermann Müller from Brno was offered annual pay of 500 gulden. This sum corresponded to conditions on the market, but Karl Zay did not like it. Müller asked for part of his pay in advance, although recruitment of other employees was only beginning at the time of his arrival - 1 September 1845 - and the equipment had still not arrived. Even decent payment conditions could not secure the stability and quality of personnel, and precisely the master dyers had the leading position in relation to their profession. By the end of May 1846, Müller was already on holiday back in Brno, and he apparently refused to return, because after a month, the directors were discussing the appointment of a replacement. The situation would be repeated in September 1847 and spring 1851. The management was beginning to suspect that Uhrovec was attracting people who craved quick and easy enrichment. ${ }^{50}$ Therefore, when seeking new employees it did not reply only on applicants attracted by advertisements. It also turned to its commercial partners especially in Moravia, but also to former employees such as H. Müller with requests for mediation. ${ }^{51}$ The offered remuneration was also increased, with the selected applicant getting initial pay of 500 gul. per year, which could increase over two years to 700 gul., while keeping other incentives. ${ }^{52}$

The personnel of the factory understandably included various categories of employees. During the construction of the factory, the work was organized directly by Karl Zay's designated management formed from his trusted economic personnel headed by the administrator Makláry. After him, the management of the factory appointed R.W. Wrchovszky, who mostly stayed in his office in Vienna, from where he organized international contacts, transport and distribution of goods

Correspondence, carton 592, p. 328.

50 Letter by the director from 27 Oct 1846 addressed to A. Heydrich in Brno. Ibidem, p. 71-72.

51 The management solved similar problems, but concerning the master fuller, with Richard Hartmann from Chemnitz, on 27 Jan 1848. Ibidem., p. 157.

52 According to a letter from 11 April 1851 addressed to H. Müller in Brno. Ibidem., p. 361-362. It is also necessary to take into account the fact that variations in pay levels and rising levels of pay caused by shortage of qualified personnel also troubled the management of the factory in other cases. 
until 31 October $1851,{ }^{53}$ the accountant Carl Szokolóczy ${ }^{54}$ and office record keeper Ludwig Gregusch..$^{55}$ The next in the hierarchy of employees were the masters of individual fields of production. Apart from the above-mentioned master dyer, they were the master spinner (Spinnmeister) Bruno Walter or R. Kanth, the master fuller (Walkermeister) Fridrich Schipelt, the master finisher (Apreturmeister) Carl Nikisch, from March 1846 also the master weaver (Webermeister) Wolf, later F. Hildebrandt. The well paid employees also included the pharmacist and the physician Burstein. The first received housing and expenses for issuing medicines, while the second received fixed pay of 250 gul. Understandably, both had additional income from private patients. During the installation of machinery, installation and maintenance personnel were hired for a considerable period through the suppliers. Later, with the development of production, the expert personnel were supplemented with a specialized locksmith (Schlossermeister) Dvorak, who was assisted by an apprentice, carpenter (Fabrik Tischler) Grünnwald and another employee of the finance department, Imrich Kollosek. Their pay was understandably differentiated. For example, in February 1846, the pay of expert employees reached a total 316 gul. $40 \mathrm{kr}$., but with the gradual increase of production, this component of expenditure also grew, in September it was already 1047 gul. and in December 1431 gul. .

The building and running of a factory understandably also involved other specialized professions. Building materials in the form of bricks were secured from the master brick-maker Vaik, supervision of the workers and recording of their activity was done by two office workers, and the factory also needed three full-time coachmen. Numerous salaried masters (tinsmiths and carpenters) were hired directly in the lordship according to need and paid in weekly intervals. Some of them were still engaged for special work later. For example, the Roma ("Gypsy") smith Johann Rácz from Uhrovec was paid for regular deliveries of special nails for frames for drying cloth. Samuel Štúr also helped with occasional work on the binding of various books of records and decrees.

The greatest burden of production and the success of the enterprise naturally lay on the direct producers: spinners, weavers, dyers, shearing and other cate-

53 DÚBRAVSKÝ, Ferdinand. Uhorská Skalica, mentions R. Vrchovský (20 Feb 1816 - 17 March 1901) originally from Skalica, as the owner of a transport firm in Vienna. The Zay property at Skalica and shared religion were apparently important influences on engaging the descendant of an important cloth-making family from Skalica. See the Zlatý fond denníka SME 2013, accessible on-line (accessed 6 Oct 2017): http://zlatyfond.sme.sk/dielo/1824/ Dubravsky_Uhorska-Skalica/11

54 Carl Szokolóczy was originally concerned not only with managing the regular operations of the factory, but also of the whole Zay estates, so from 1849 the accounts of the factory were taken over by Michael Brand.

55 He was probably the son of a Bučany gardener. 
gories of textile workers. Their number has been guessed in the secondary literature, but the records of the factory medical fund enable us to reconstruct the exact number for every week of the working year. An average of 75-90 workers of both sexes were employed in various tasks concerned with the productive process in the first year of activity. In the revolutionary year 1848, as recorded from 7 February to 30 December, there were $71-90$ workers each week, while after settlement of the situation, in the period 7 February to 31 March 1849, the number of workers varied in the range 113-149. However, it is necessary to mention the anomaly of weeks during which the number of workers showed an extreme decline or the opposite. From 19 June to 10 July there were 54-57 employees, while during the middle week only the spinning section operated with 12 workers. This decline can be hypothetically attributed (if we do not take into account the possibility of incomplete records) to uncertainty connected with the introduction of the new Hungarian currency and an associated limitation of production. A similar situation also occurred in the first two weeks of October, when the number of workers declined from the usual autumn figure of 77-80 to 49 and 52. A state of emergency had been declared and soon suspended. The imperial army had been ordered to suppress the revolution in Hungary. From the beginning of November the situation at the factory stabilized with the engagement of about 80 workers. Extreme growth came in the week from 20 January 1849, when as many as 219 workers alternated at the machines. Approximately from the autumn of 1848 the factory was engaged in making cloth for the uniforms of the county military units and the first orders from the Monturs Commission. However, due to the confused situation, supply and payments slowed down. ${ }^{56}$

The Uhrovec factory was also a pioneer in the field of employing women. ${ }^{57}$ The textile industry rapidly became their domain. However, it was less frequent in this period for women to reach the position of mistresses, or there simply is not enough evidence about the organization of work in the first manufacturing enterprises and factories. However, in the case of Uhrovec, women made up half the workforce contributing to the healthcare fund. ${ }^{58}$ They also came to work from more distant localities and were dependent on factory accommodation to a considerable extent. Their work was directed by mistresses, who were selected by the management on the basis of "competition". However, assessment of their quality seems to have been rather problematic at the beginning. In summer 1846,

56 See SNA, Zay - Súkenka, Correspondence, carton 592, letter from 23 Jan 1849.

57 I will leave aside for now the question of work houses, where women worked, but under compulsion, rather than in conditions of commercial employment. On the phenomenon of work houses see ŠPIESZ, ref. 4, p. 228-238.

58 For example, in the first half of 1849 the workers in the factory included 35 men and 58 women. 
the management asked its reliable partner Heinrich Heydrich of Brno whether it could provide a verified unnamed applicant, because it had a free place for a mistress and seven women had applied for it! It is not surprising considering that pay conditions were not bad: The weekly pay of 3 gul. represented more than 150 gul. per year, and there was also free accommodation and heating. On the other hand, however, precisely the female workers were the variable element in the workforce, and commercial correspondence from this period sometimes contains complaints about the shortage of a category of women workers called Nopperinnen in German.

After the launching of production and development of trade, another important category of worker increased: Apart from the direct factory employees, we can identify the chief of stores of stocks and produced goods (Magaziner), de facto head of trade in Uhrovec Johann Schnittar, who was followed by Jozef Molitorisz, and with some benevolence also the chief trade reperesentative in Pest - F. Makláry, and Pressburg - Johann Kodrits/Köttrich. From 1846, precisely these men had the main role in seeking commercial partners, distributing goods, negotiating deals and representing the factory in the places of their activity. Karl Zay himself often visited both shops. Makláry also belonged to the circle of Zay's close friends..$^{59}$ Obtaining and fulfilling large order depended precisely on his ability to establish contacts with the central authorities. The textile factory soon opened more shops, where they concentrated orders from different regions. The factory was represented by shops in Trnava (Eduard Richter) and Trenčín (Jozef Tejfelesi). In 1847, shops in Deutsch Altenburg and Györ were briefly added with further applications. ${ }^{60}$ However, the turbulent year 1848 reduced the number of shops to four: Uhrovec, Pressburg, Nitra (Ladislav Trsztyenszky) and Pest, although other businessmen applied to represent the factory in this period, including M.S. Boschán of Miskolc.

In reality, these "company" shops carried out commission sales, with the shopkeeper or owner of the shop undertaking "standardized" deals. The expense of running the shop and transporting goods were the responsibility of the shopkeeper, because he was the owner of the commercial premises. However, Zay wanted to give the external appearance of the shops a unified appearance, and insisted that the owner of a shop should display a shield or board of consistent design provided by the factory. ${ }^{61}$ Goods were sent to the sellers on the basis of invoices (Franco), but remained the property of the factory until they were paid

59 Zay's regular visits to the shop in Pressburg are shown by numerous entries in his diary from the appropriate years. SNA, Zay - Karol Zay, Mária Kollowrat (denník), carton 220.

60 On 15 Feb 1846, Franz Gerometta of Žilina endeavoured to open a shop, but it was refused, as were those of F.L.A. Burian of Kremnica and Andreas Skultety of Žilina on 14 Feb 1848.

61 Winkler and Deutsch are mentioned as painters without further details. 
for. The shopkeeper was supposed to send payments monthly, but in practice there was frequent and sharp correspondence resulting from late payments. The factory also set the condition that the shop would not sell similar products from other producers. However, it granted a provision of $2 \frac{1}{2}$ kreuzers from every hundred kreuzers in sales. This was soon changed to the more regular 5\% rebate. Shopkeepers competed to gain the status of factory shop, because they undoubtedly promised unproblematic deliveries of goods, and any return of unsold goods was not a serious problem. Fixed shops were a more consistent and so more advantageous way of marketing goods than the traditional displaying of goods at markets and fairs. However, these still had their place in commercial life, and supplies were regularly produced for the dates they were held. The most valued was the St. John's Market in Pest, where traders from the whole Kingdom of Hungary gathered. The further possibility of presentation at industrial exhibitions was rapidly developing, but these became really important only after the period of interest of this study.

In various cases shopkeepers failed to correctly estimate the quantity of goods to order and could not sell them. They did not pay their invoices to the factory in time, and this began to harm supplier - customer relations. Reminders to pay invoices followed and sometimes threats of judicial action. Payment discipline was especially loose in the spring of 1848, when the unclear situation and breakdown of security in Hungary hindered trade. ${ }^{62}$ These reminders were successful, and it is interesting that after the settlement of debts, the management of the factory continued to cooperate with former creditors. It clearly understood the difficulties of doing business, because it also got into situations where nonpayment threatened for goods it had ordered: dyes or components. Reminders for debts were, therefore, accompanied by references to the idea that the factory should not fall into debt, or, at least, should not leave bills unpaid for long and risk its good name. We can perceive here the ethos of the aristocratic owner with a traditional idea of the concept of aristocratic honour, but also of a time when business was still carried on more or less on the personal level and "reputation" was an important commercial advantage.

However, the management of the factory also encountered considerable problems with fulfilment of orders. For example, it had this experience with the supplier of finishing machines for Ernest Pflieger from Bielitz, who sent machines intended for Uhrovec to an entirely different customer, and delivered them only after receiving a reminder. This cost the supplier a deduction from transport costs. However, a piquant detail is that the incorrect destination of the machines was another of the commercial partners of the factory, namely Hartmann of

62 See the letters to Köttrich in Pressburg, L. A. Burian in Kremnica, Ladislaus Trsztyanszky in Nitra, and A. Skultety in Žilina from 17 April 1848. 
Chemnitz, which was supposed to supply similar machines. The management learnt about this but did not withdraw from either contract because it assumed the need for rapid expansion of production and the use of both deliveries.

\section{The factory and various types of order}

It was not easy to achieve profitability in the highly competitive textile industry. Advertising was already regularly applied in support of products. The textile factory advertised in the newspapers Pesti Hirlap, Magyar Gazda, Jelenkor, Buda-Pesti Hiradó, Hetilap, Pester Zeitung and Pressburger Zeitung, but information about it also appeared in foreign newspapers. The factory had prepared samples of fabrics, which were available in its shops, and on their basis, it agreed estimated quantities. The offered materials included cloth and materials of varying quality - for uniform, livery, cloth for horse blankets, trouser materials, seasonal materials for summer or winter, and all in various colours. It also received proposals for products from the shopkeepers, but with the condition of a period of up to about three months. Small customers were an important type of client, but problems with the payment of invoices persuaded the management to seek large customers, namely organizations that needed clothing or uniforms for their members. They included various lordships, which provided livery for some categories of their employees ${ }^{63}$ county authorities, which clothed their guardian$\mathrm{s},{ }^{64}$ the army or individual military units, the administrators of chamber lordships and after the revolution also county military units, home guard and gendarmerie. In spite of the complex situation in transport and the securing of payments, precisely the revolution was a motor of production at Uhrovec: the military units of the counties of Hont, Trenčín, and Nitra had more than a thousand members and needed regular uniforms, often in national colours. The orders went precisely to Uhrovec.

The uniforms provided a high degree of stability of production, but this accompanied by a lower price. The fact that the factory was burdened by production for the needs of the imperial army is shown by documents concerning orders from the side of the Hungarian Monturs-Commission ${ }^{65}$ Precisely the first

63 In this period they included the Erdödy lordship of Továrniky, the lordship of Count Königsegg-Aulendorf, the Levice lordship of Prince Eszterházy, the lordship of Count Hunyady. Liveries required higher quality cloth of the Tosking type, often coloured.

64 The counties of Hont and Liptov in 1847.

65 The commissions established in individual lands of the Monarchy were responsible for the delivery of uniforms and supplies. See MÜLLER, Franz. Die kaiserl. königl. österreichische Armee seit Errichtung der stehenden Kriegsheere bis auf die neueste Zeit: Nebst einer Beigabe: Notizen über die Bewaffneten Bürgen -Corps der größeren Städte der Monarchie. Band 2, Prag 1845, p. 228-230. 
orders from summer to autumn 1848 were problematic for the management of the factory, because the price was considered too low. ${ }^{66}$ In addition, production during this hectic period was complicated by the collapse of a wall and the associated damage to the waterwheel driving the fulling equipment, which stopped production for three weeks. To avoid sanctions, a confirmation from a court that an event really happened had to be submitted to the commission. ${ }^{67}$ In spite of problems, cooperation with the commission was a stabilizing factor, because the quantity of ordered cloth amounted to thousands of yards. The first order from the Monturs-Commission represented 6,000 yards of grey and brown cloth. In January 1849 , a time of the greatest confusion in the country, this was a welcome source of stabilization of production. Further orders already represented much larger quantities. For example, the order from 3 and 5 January 1850 with a delivery deadline at the end of July, intended for units of the newly organized gendarmerie, represented 15,000 yards of blue cloth (36 kreuzers), 7,500 yards of brown (40 kr.) and 7,500 yards of steel-green (40 kr.). 6,000 yards had to be delivered by the end of March, and then another 6,000 yards every month up to the end of July $1850 .{ }^{68}$

The number of orders increased in the following years, but the financial effect was not very satisfactory. ${ }^{69}$ The commission decided for itself the purchasing price and it was not easy to negotiate adjustments according to the real cost of wool. However, in the case of the above mentioned order it succeeded and the price of two types of cloth was increased: blue cloth from 36 to $42 \mathrm{kr}$. a yard, and green from 40 to 47 , but the price of brown cloth was reduced from 40 to $30 \mathrm{kr}$., so that the profit was more or less marginal in spite of some increase in price.

In comparison with commercial orders, the difference between the real price and that determined by the commission is even more substantial. In 1850, the quantity of commercial output reached only 20,000 yards of cloth, but with a

66 Letter addressed to the shop in Pest on 4 Sept 1848. SNA, Zay - Súkenka, Correspondence, carton 592, p. 221-222.

67 Letter addressed to the shop in Pest 26 Sept 1848. Ibidem, p. 226-227.

68 Payments would be made by the firm Pollak und Poppers Söhne.

69 Data according to SNA, Zay - Súkenka, Correspondence, carton 592.

\begin{tabular}{|l|r|r|r|r|}
\hline \multicolumn{5}{|c|}{ SUMMARY OF DELIVERIES OF CLOTH, 1850-1859 } \\
\hline Year & \multicolumn{2}{|c|}{ Montur-Commission } & \multicolumn{2}{c|}{ Other orders } \\
\hline & Quantity & Price in gul. & \multicolumn{1}{c|}{ Quantity } & Price in gul. \\
\hline 1850 & 30000 & 50000 & 20000 & 55000 \\
\hline 1853 & 35000 & 65000 & 22000 & 80000 \\
\hline 1859 & 56400 & 145000 & 8000 & 15000 \\
\hline
\end{tabular}


value of 55,000 gulden! Deliveries for the Monturs-Commission were also problematic because officers found faults, either real or imagined, in the delivered cloth, which led to them demanding reduced prices. Slightly different shades of colour, impermanent colour, irregular width and faults in weaving are mentioned. The management of the factory reacted to the complaints with observation that if they removed all faults, the delivered cloth would be of higher quality than the samples submitted by the commission. The demand that the factory had to commit itself to reject other offers and so lose advantageous seasonal orders for "fine" cloth from regular partners during the whole spring was especially problematic. ${ }^{70}$ At the same time, this was not the only complication associated with supplying the army. The commanders of some Hungarian regiments were not sure whether goods should be delivered directly through commercial representatives in Pest or through the headquarters of the Monturs-Commission. However, that would have meant sending rolls of cloth to Vienna and paying customs duties that still applied to trade between Austria and Hungary. This method of delivery would also have been entirely illogical, especially in the case of orders for the fifth gendarmerie regiment stationed in Košice. This deal was agreed directly by Karl Zay with the commander of the regiment Ignaz von Talian after completion of the problematic contract with the Monturs-Commission from the beginning of the year.

The reaction of the commercial management of the factory to the demands of the commission shows that it was not very favourably inclined to such interventions by the owner in commercial policy. The blocking of part of the productive capacity was complicated by the not particularly good prices and problems with maintaining the quality of production. In a letter addressed to Ferenc Makláry in Pest, the director Wrchovszky clearly stated that "the whole transaction with the gendarmerie looks like a loss. The deal should never have been concluded..." When the change of commander was followed by misunderstandings regarding the method of delivery, the whole contract was stopped, and customers for the already produced cloth were quickly sought, also using newspaper advertisements. They included the gendarmerie in Milan, Vienna or Nagyvárad (Oradea, Romania). Therefore, when Karl Zay mentioned in a letter from 20 May 1851 the possibility of a new order from the gendarmerie, the director of the factory thought it would be best if they did not accept it quickly, but only on direct urging and with the excuse that production would begin only when a continuing contract was completed. ${ }^{72}$

70 The types Elastiques, Mousselins, Trapp croisie, Kornblau and winter textiles were designated as such..

71 Letter from 15 Jan 1851. SNA, Zay - Súkenka, Correspondence, carton 592, p. 344-345.

72 Letter addressed to Karl Zay in Pressburg on 24 May 1851. Ref. 71 p. 369-370. 
The unambiguously formulated position and recommendations of the director on how to proceed further testify to the emerging dispute between him and the owner of the enterprise. On one side, the aristocrat with a feeling for representation, loyalty and service to the monarch and his institutions, on the other side the operational director, responsible for the everyday running of a factory struggling with shortage of workers, limited cash-flow, growing costs and sometimes excessive demands from customers. The director proposed some basic principles for negotiating a new contract with the gendarmerie. It should be discussed only after the sending of the last delivery. They should insist on the condition of a limited quantity of contracted goods with no more than 36,000 yards a year in quarterly deliveries, and payment in cash. The specification of the quality of the cloth had to be a matter of general inspection. However, the factory wanted to guarantee only one standard width of a bale of cloth and calculate the price not by the length, but by the area of the delivered quantity. The lowest acceptable price for a yard also had to be determined according to the type of cloth in the range 2 gul. $30 \mathrm{kr}$. -3 gul. $24 \mathrm{kr}$. When shortly after in connection with the delivery for Vienna, the director wrote about "immense (financial) losses" with a difference between costs and income for goods of 9,832 gul. $25 \mathrm{kr}$., caused by the need to buy "foreign" wool at a higher price when there was not enough of their own, and after a few months, on 31 October 1851 he gave up his position, it is clear that the dispute had acquired great intensity and could have far-reaching consequences for the enterprise. After several years, Wrchovszky returned to his native town, ${ }^{73}$ while the factory continued its effort to balance between relatively secure deliveries for the state and lucrative but risky production of goods according to demand.

\section{“Colonien von Proletarier zu begründen habe ich keine Lust”: social aspects of running a factory}

From the beginning, the factory with importance for the whole Kingdom of Hungary had immense importance for shaping social relations in the Uhrovec valley. Dozens of local inhabitants gained work already during the construction and equipping of the factory, during production, and in delivery of the products. However, the number of workers understandably varied according to orders and the state of the factory's finances. While deliveries to county units, the army and gendarmerie were not occurring, production was oriented towards various woollen textiles, representing "normal" and seasonal output - materials for clothes, trousers, coats or livery. In 1846, a specific type of product already appeared: tricolor on hat brims, which became part of "national" dress in the

73 See Ref. 53. 
pre-March period. Karl Zay had already considered supplementing output with production of luxury goods. For this reason he brought a large group of lacemakers from Bohemia to Uhrovec. However, Pál Rázgha, Zay's associate in efforts to reform relations in the Lutheran Church, persuaded the Count not to take this step. Knowing the situation in Bohemia, where he worked at this time, he predicted that they would not succeed in competing with mechanized production, and the "mentally and physically deformed people" would become a school for proletarians and pauperism. ${ }^{74} \mathrm{He}$ saw in this phenomenon a potential danger for the social relations of the locality and the whole of Hungary.

This view, which K. Zay also adopted ${ }^{75}$ expressed fear of the excessive concentration of a social group with unforeseeable behaviour, not directed by the hitherto usual relations based on personal connections and paternalism. Zay, wellread in the economic literature of the time and well-informed about events in the more developed countries, feared the outbreak of socially motivated unrest, and was one of the first in the society of the time to point to the danger of communism. However, in the initial phase of the existence of the factory, the management did not have to deal with expressions of social tension. It was faced more with unevenness in the availability of enough workers, the quality of their work and the results for the process of production. More than one explanation of delays to agreed deliveries was based on shortage of experienced workers. Comparison of the summaries of wage payments in the initial period of the factory and during the period of large-scale production for the army also testifies to this. In 1846, the wages of workers and other factory personnel reached 31,336 gul. $16 \mathrm{kr}$., but in 1850 it was less with only 27,899 gul. $46 \mathrm{kr}$. The constant delays to agreed deliveries threatened the income and credibility of the factory and the existence of ordinary workers. The situation was not helped by the preservation of a relic of the traditional model of preparation of workers in the guild system, namely the engagement of apprentices and journeymen in the factory.

A natural reaction to the growing workload associated with deliveries for the army was demands for higher pay, which represented an unexpected situation for the management. The state of latent tension was more or less permanent, and clearly it was only a matter of time before the first signs of social unrest appeared. In spite of this, nothing happened. Work in a modern factory provided a higher income, while a flat and some degree of social security could also be attractive. Employees had the definite advantage of medical insurance. In return for a regular payment, the cost of treatment during illness was covered. This fund

74 Diary of K. Zay from 12 April 1845. SNA, Zay - Karol Zay, Mária Kollowrat (diary), carton 220.

75 K. Zay used these words in the subtitle of the diary entry from 2 Feb 1846, as a reaction to the offer to settle 20-40 small farming families in Uhrovec. Ibid. 
arose according to the insurance model. Every employee, including members of the management, had an obligation to contribute without distinction.

The medical fund functioned on the basis of the comprehensive statute from 1 November 1847, which articulated in a modern form the interest of the employers in the best conditions for their workers. ${ }^{76}$ The declared interest was not only an outward gesture, it clearly expressed Count Zay's internal conviction of the need for such measures. Zay himself gave the fund its largest deposit: 125 gul. His example was followed by other members of the management of the factory - office workers and masters - with sums varying in the range 10-25 gul. However, the fund regularly grew from the obligatory contributions of all employees, which were determined as payments in two forms. On entering employment, all workers including journeymen had to irreversibly deposit one gulden ${ }^{77}$ from their first pay and then 6 kreuzers every week. A reduced payment was also expected during convalescence, when they were already capable of doing easier paid work. Payment discipline was secured with the threat of a fine in the event of late payment, amounting to double the obligatory weekly payment.

Thanks to the rational system of payments, the amount saved in the three months from the origin of the fund to the end of January 1848 reached 553 gul. $12 \mathrm{kr}$., and at the time of a further check on 18 October 1848, there was 936 gul. $14 \mathrm{kr}$. Part of the accumulated sum was regularly deposited in the factory fund, which increased its value by deposit in a savings bank. On 18 October 1848, 500 gul. had been deposited, on 31 December 1849 only 300 gul. remained, but on 31 December 1850 there was again 400 gul. If the deposited capital and the interest on it reached a sufficiently high level, the weekly payments of the employees could be reduced or suspended, but this did not happen.

Management of the money was subject not only to the usual accounting controls, but also to the oversight of the whole factory personnel. The fund and its account book were administered by one employee in the factory office and three members of the "factory personnel", but the management carried out continual monitoring. Every quarter year all the employees were informed about the state of the fund and the management of it. The employees could be convinced that the fund was providing contributions to sick workers, even over a period of weeks. The fund actually provided real support, specifically $25 \mathrm{kr}$. a day, as well as free medical examination and medicine, to those who were not able to work because of illness. The average period of support during illness during the first three years (up to 31 December 1848) was 4.14 days. This figure derives from

76 Statuten des Kranken Fonds und Namens Verzeichniß der theilhabenten Mitglieder. SNA, Zay - Súkenka, Nemocenský fond - účtovné knihy, účty, roky 1847-1873, carton 598.

77 When re-entering employment, they paid half this sum. Apprentices had to pay 2 gul. on completing their training. 
219 sick people, who missed 1,127 days of work, but this average is affected by long term support, for example, five weeks for Franz Thomas and four weeks for Johann Hnatek. In the event of death, insured persons could rely on appropriate assistance: 4 gul. towards funeral expenses and the possibility of payment for bell-ringing, which was significant especially for non-local workers. Even without direct or quick family support, they were not condemned to an undignified burial.

\section{Conclusion}

The Uhrovec textile factory was a modern enterprise, which gained a place among the most important businesses of its type in the Kingdom of Hungary. However, it can be described as a "green-field" business project established in a region with only minimal material conditions in the form of wool production and no infrastructure in terms of a communication network and urban centres. However, its success generated further business projects. A year after the establishing the textile factory, the founder himself, Karl Zay began to prepare to start a glass works and sugar refinery in nearby Podlužany. ${ }^{78}$ The project also had another comparative advantage, namely strong initial capital, which only the owner possessed. No less important was the associated social capital. As a rich aristocrat, he had a multitude of connections, which enabled him to successfully establish himself in the economic space of Upper Hungary. The owner himself gained for the factory investors and customers among his aristocratic friends and acquaintances. Visits to the factory's Pressburg shop were part of his daily routine during his stays in the city. Count Karl Zay was an adherent of liberalism before 1848 not only in relation to the political organization of Hungary, but especially concerning its economic development. He also actively supported other progressive enterprises such as the building of railways, and was able to establish good relations with stable customers, especially from the ranks of the army and gendarmerie. However, state orders also represented a risk factor in the form of unrealistic conditions set by the customers, which gradually began to threaten the profitability of the enterprise. The factory operated until the 1870 s, when the Zays were forced to sell it after the death of the founding father. Glass production found a place in the premises of the former textile factory. This was the beginning of a new stage of business at Uhrovec.

* The study originated in the framework of the project APVV-15-0349 The individual and society - their mutual reflection in the historical process.

78 Diary of K. Zay from 2 March 1846. SNA, fond Zay - Karol Zay, Mária Kollowrat (denník), carton 220. 


\section{UNTERNEHMERTÄTIGKEIT IN DER REGIE EINES ARISTOKRATEN: GRÜNDUNG UND ERSTE JAHRE DER TUCHFABRIK} IN UHROVEC (1845-1851)

\section{EVA K O WA L S K Á}

Die (Fein)Tuchfabrik in Uhrrovec ist ein bisher unbekanntes, aber doch ausreichend aussagekräftiges Beispiel für die Errichtung einer Fabrik „auf der grünen Wiese“. Sie entstand in einer Region, die dazu keine ausreichenden materiellen und infrastrukturellen Voraussetzungen hatte. Das Projekt hatte jedoch einen anderen komparativen Vorteil - ein starkes Kapital, über das der Eigentümer, ein wohlhabender Aristokrat mit Beziehungen, die ihm eine erfolgreiche Etablierung im wirtschaftlichen Bereich von (Ober)Ungarn ermöglichten, verfügte. Der Graf Karol Zay war ein Anhänger des Liberalismus nicht nur in Bezug auf die politische Anordnung von Ungarn vor 1848, sondern auch auf seine wirtschaftliche Entwicklung. Er hat auch andere progressive Geschäftsabsichten (Eisenbahnbau, Dampfschifffahrt) unterstützt und war in der Lage, eine Geschäftsbeziehung mit einem stabilen Kunden - Armee und Gendarmerie - aufzunehmen.

Die Studie analysiert den Prozess des Aufbaus der Fabrik, finanzielle Seite des Baus und der Einrichtung, Fragen der Personal- und Materialfunktion, sowie die Fragen der sozialen Sicherheit der Arbeiter (ein bedeutender Teil von ihnen waren Frauen). Die Fabrik hatte mehrere Firmengeschäfte und ein Netz von Abnehmern in Ungarn. Während der Revolution begann sie aus den Lieferungen für die Armee, Militia Portalis und Gendarmerie zu profitieren. Die öffentlichen Aufträge haben jedoch gleichzeitig einen Risikofaktor in Form von unrealistisch eingestellten Bedingungen seitens der Abnehmer dargestellt, die allmählich die Rentabilität des Geschäfts zu gefährden begannen. Gleich am Anfang dieser Zusammenarbeit verzeichnete die Fabrik einen Verlust, der ihren Betrieb zu gefährden begann.

PhDr. Eva Kowalská, DrSc., Historický ústav SAV

Klemensova 19, 81499 Bratislava

e-mail: eva.kowalska@savba.sk 